\title{
A study of risk factors for preterm labour
}

\author{
Shannon F. Fernandes ${ }^{1}$, Savita Chandra ${ }^{2}$ \\ ${ }^{1}$ Department of Obstetrics \& Gynaecology, Father Muller Medical College, Mangalore, Karnataka, India \\ ${ }^{2}$ Department of Obstetrics \& Gynaecology, Goa Medical College, Goa, India
}

Received: 07 July 2015

Revised: 09 July 2015

Accepted: 13 August 2015

\section{*Correspondence:}

Dr. Shannon F. Fernandes,

E-mail: ferns4@rediffmail.com

Copyright: () the author(s), publisher and licensee Medip Academy. This is an open-access article distributed under the terms of the Creative Commons Attribution Non-Commercial License, which permits unrestricted non-commercial use, distribution, and reproduction in any medium, provided the original work is properly cited.

\begin{abstract}
Background: Preterm births continue to be the leading cause of perinatal and neonatal morbidity; representing one of the principal targets for obstetric health care and challenging the obstetrician to tackle this problem by focussing on the preventive approach.

Methods: This study was conducted in the department of Obstetrics and Gynaecology of a tertiary centre during the period from $1^{\text {st }}$ October 2010 to $29^{\text {th }}$ February 2012. Patients presenting between 28 and 37 weeks in preterm labour were included in this study. Patients enrolled into the study were subjected to a detailed history with respect to age, parity, previous pregnancy outcomes and to identify the presence of any risk factors in this pregnancy including presence of GDM, PIH, anemia or any other medical disease. A thorough obstetric and systemic examination was done for the presence of hydramnios and multiple gestation. Data was analysed using Pearson's Chi square test.

Results: The study showed the incidence of preterm births to be $7.81 \%$. The maximum number of cases belonged to the age group 20-29 years. $15.8 \%$ belonged to the extremes of reproductive age group. $12.11 \%$ had a history of previous preterm births. However, $35 \%$ of patients in the study who presented in preterm labour had a previous history of abortions. The significant risk factors found to be associated with preterm labour were hypertensive disorders, antepartum haemorrhage, malpresentations, multiple gestation, UTI and presence of vaginal infections.

Conclusions: If we take into account the increase in multiple pregnancies and induced preterm birth, spontaneous preterm birth in singleton pregnancies has probably decreased. This decrease in preterm birth is undoubtedly related to better prenatal care for all pregnant women. The recognition of risk factors for preterm labour constitutes a part of basic prenatal care. Most etiological factors are modifiable, and preconception counselling should emphasize and address these issues.
\end{abstract}

Keywords: Preterm labour, Etiology, Risk factors

\section{INTRODUCTION}

Preterm labour is defined as onset of regular uterine contractions associated with cervical changes starting before 37 completed weeks of gestation, with or without intact fetal membranes.

The American Academy of Paediatrics and the American College of Obstetrics and Gynaecology (1997) proposed the following criteria to diagnose preterm labour.
1. Contractions of 4 in 20 minutes or 8 in 60 minutes plus progressive cervical change

2. Cervical dilatation greater than $1 \mathrm{~cm}$

3. Cervical effacement of $80 \%$ or greater

Estimates of preterm birth rates range from $5-10 \%$ in developed countries to $25 \%$ in developing countries. ${ }^{1}$

The worldwide incidence of premature birth ranges between 6 and $11 \%$. $^{2}$ 
According to Copper et al. preterm birth occurs in $7 \%$ to $11 \%$ of pregnancies but is responsible for $85 \%$ of neonatal deaths in normally formed infants who do not have any congenital anomalies. ${ }^{3}$

$30-40 \%$ of all cases of preterm birth are due to elective delivery for a maternal or a fetal complication where it is judged that the fetus is better delivered in the mother's interest or that of its own. ${ }^{4}$ The remaining $60-70 \%$ of preterm births are likely due to sub-clinical infective / inflammatory processes, cervical dysfunction, multiple gestations, idiopathic and possible social, nutritional, and environmental interactions.

\section{METHODS}

This study was conducted in the department of Obstetrics and Gynaecology of a tertiary hospital during the period from $1^{\text {st }}$ October 2010 to $29^{\text {th }}$ February 2012.

Considering the facilities at the neonatal unit of the institution, 28 weeks was taken as the lower limit for period of viability for this study.

Gestational age assessment was done at admission.

Patients who entered the third trimester of pregnancy and were diagnosed as a case of threatened preterm labour or preterm labour were included in this study.

A patient was said to be in threatened preterm labour if she presented with pain abdomen and had uterine contractions without any cervical changes.

A patient was said to be in preterm labour if she presented with the following:

1. Contractions of 4 in 20 minutes or 8 in 60 minutes plus progressive cervical changes

2. Cervical dilatation greater than $1 \mathrm{~cm}$

3. Cervical effacement of $80 \%$ or greater

Any patient whose pregnancy was terminated preterm for any maternal or fetal indication was also included in the study. Patients who presented with leaking per vaginum or antepartum haemorrhage were included.

\section{Exclusion criteria}

- Pregnancy beyond 37completed weeks

- Pregnancy before 28 weeks

- Patients referred with intra uterine fetal demise were excluded due to inadequate information.

- Patients who were initially admitted as threatened preterm labour and responded to management and were subsequently discharged or delivered at term were excluded from further analysis.
410 cases were found to be suitable for inclusion, from among 5246 in the above period.

A control group was selected from the same population presenting to the hospital in the same time frame as the study. These patients were randomly selected from among those patients admitted in labour, presenting beyond 37 completed weeks of gestation with no risk factors which are listed as risk factors for preterm labour in this study.

Patients enrolled into the study were subjected to a detailed history with respect to age, parity, previous pregnancy outcomes and for the presence of any risk factors in this pregnancy including GDM, PIH, anaemia or any other medical disease. A thorough obstetric and systemic examination was done for the presence of hydramnios and multiple gestation. All patients were subjected to at least one ultrasonographic examination and urine culture and vaginal swab was sent.

\section{RESULTS}

\section{Incidence}

The total no of deliveries in the hospital of patients beyond 28 weeks were 5246 .

196 patients presented with threatened preterm labour. 410 patients presented in preterm labour, giving an incidence of preterm births of $7.81 \%$.

Out of the 410 cases, maximum cases of preterm labour were in the age group of 20-29 years (67.9\%). 27 were teenage pregnancies and 38 were elderly. Therefore, extremes of reproductive age groups accounted for $15.8 \%$ of cases as compared to $15.6 \%$ of controls.

This association was found to be statistically significant (Table 1).

Table 1: Distribution of cases according to age incidence of preterm labour.

\begin{tabular}{|lllll|}
\hline $\begin{array}{l}\text { Nases } \\
\text { years }\end{array}$ & 27 & $6.5 \%$ & 19 & $7.6 \%$ \\
\hline $\begin{array}{l}20-24 \\
\text { Years }\end{array}$ & 132 & $32.2 \%$ & 98 & $39.2 \%$ \\
\hline $\begin{array}{l}25-29 \\
\text { years }\end{array}$ & 145 & $35.7 \%$ & 77 & $30.8 \%$ \\
\hline $\begin{array}{l}30-34 \\
\text { years }\end{array}$ & 68 & $16.5 \%$ & 36 & $14.4 \%$ \\
\hline $\begin{array}{l}\geq 35 \\
\text { years }\end{array}$ & 38 & $9.3 \%$ & 20 & $8 \%$ \\
\hline Total & 410 & $100 \%$ & 250 & $100 \%$ \\
\hline
\end{tabular}

Chi-square test for extremes of age: $\mathrm{X}^{2}=6.0403 ; \mathrm{p}=0.0140$ 
In this study, 187 were primigravidas $(45.61 \%)$, while the rest were multiparous $(54.39 \%)$.

The $\mathrm{p}$ value for distribution of cases by gravidity was not found to be statistically significant (Table 2).

Among the multiparous presenting in preterm labour, 116 $(50.02 \%)$ were gravida $2,84(37.67 \%)$ were gravida 3,20 $(8.7 \%)$ were gravida 4 and there were 3 cases of grand multipara (Table 3).
Table 2: Breakup of patients with respect to gravidity.

\begin{tabular}{|lllll|} 
Gravidity & $\begin{array}{l}\text { No. of } \\
\text { cases }\end{array}$ & $\begin{array}{l}\text { Percentage } \\
(\mathbf{n}=410)\end{array}$ & $\begin{array}{l}\text { No. of } \\
\text { controls }\end{array}$ & $\begin{array}{l}\text { Percentage } \\
(\mathbf{n}=250)\end{array}$ \\
\hline Primigravida & 187 & $45.61 \%$ & 112 & $44.8 \%$ \\
\hline Multigravida & 223 & $54.39 \%$ & 138 & $55.2 \%$ \\
\hline Total & 410 & $100 \%$ & 250 & $100 \%$ \\
\hline
\end{tabular}

Chi-square test: $X^{2}=0.0149 ; p=0.9028$

Table 3: Distribution of cases according to parity.

\begin{tabular}{|c|c|c|c|c|c|}
\hline Parity & $\begin{array}{l}\text { No. of } \\
\text { cases }\end{array}$ & $\begin{array}{l}\text { Percentage } \\
(n=223)\end{array}$ & $\begin{array}{l}\text { No. of } \\
\text { controls }\end{array}$ & $\begin{array}{l}\text { Percentage } \\
(n=138)\end{array}$ & $\mathrm{X}^{2}$ \\
\hline G2 & 116 & $50.02 \%$ & 97 & $70.28 \%$ & $\begin{array}{l}X^{2}=11.022 \\
p=0.0009\end{array}$ \\
\hline G3 & 84 & $37.67 \%$ & 36 & $26.1 \%$ & $\begin{array}{l}X^{2}=4.6436 \\
p=0.0312\end{array}$ \\
\hline G4 & 20 & $8.97 \%$ & 4 & $2.9 \%$ & $\begin{array}{l}X^{2}=4.1302 \\
p=0.0421\end{array}$ \\
\hline G5 & 2 & $0.9 \%$ & 1 & $0.72 \%$ & $\begin{array}{l}X^{2}=0.1776 \\
p=0.6735\end{array}$ \\
\hline G6 & 1 & $0.45 \%$ & - & - & $\begin{array}{l}X^{2}=0.0589 \\
p=0.8083\end{array}$ \\
\hline Total & 223 & $100 \%$ & 138 & $100 \%$ & \\
\hline
\end{tabular}

The $\mathrm{p}$ value for distribution of cases according to parity was significant.

Out of the 116 multiparous patients who were pregnant for the second time, $26.72 \%$ has a prior history of 1 abortion and 10 patients had a history of preterm labour in previous pregnancy (Table $4 a$ ).

Table 4a: Breakup of cases with past pregnancy risk factors gravida 2: $(n=116)$.

\begin{tabular}{|c|c|c|c|c|}
\hline & Past history & $\begin{array}{l}\text { No. of } \\
\text { cases }\end{array}$ & $\begin{array}{l}\text { Percentage } \\
(n=116)\end{array}$ & $\begin{array}{l}X^{2} \\
p \text { value }\end{array}$ \\
\hline \multirow{2}{*}{$\mathrm{G} 2$} & One abortion & 31 & $26.72 \%$ & $\begin{array}{l}X^{2}=28.227 \\
p=0.0000\end{array}$ \\
\hline & $\begin{array}{l}\text { One preterm } \\
\text { birth }\end{array}$ & 10 & $8.62 \%$ & $\begin{array}{l}X^{2}=6.9531 \\
p=0.0084\end{array}$ \\
\hline
\end{tabular}

Both these past histories were found to have significant statistical associations with preterm labour in the present pregnancy.

Out of the 84 multiparous patients who were pregnant for the third time, $41.67 \%$ had a history of 1 abortion. This association was found to be statistically significant.

7.14\% had a history of 1 abortion followed by a preterm birth in previous pregnancies.

$5.95 \%$ has history of 2 abortions prior to the present pregnancy.
$4.76 \%$ had history of 1 preterm birth and $3.57 \%$ had history of the 2 preterm births prior to this pregnancy (Table 4b).

Table 4b: Gravida 3: $(n=84)$.

\begin{tabular}{|llll|}
\hline Past history & $\begin{array}{c}\text { No. of } \\
\text { cases }\end{array}$ & $\begin{array}{l}\text { Percentage } \\
(\mathrm{n}=84)\end{array}$ & $\begin{array}{l}\mathrm{X}^{2} \\
\mathrm{p} \text { value }\end{array}$ \\
\hline One abortion & 35 & $41.67 \%$ & $\begin{array}{l}\mathrm{X}^{2}=19.208 \\
\mathrm{p}=0.0000\end{array}$ \\
\hline Two abortions & 5 & $5.95 \%$ & $\begin{array}{l}\mathrm{X}^{2}=0.9938 \\
\mathrm{p}=0.3188\end{array}$ \\
\hline $\begin{array}{l}\text { One preterm } \\
\text { birth }\end{array}$ & 4 & $4.76 \%$ & $\begin{array}{l}\mathrm{X}^{2}=0.6034 \\
\mathrm{p}=0.4373\end{array}$ \\
$\begin{array}{l}\text { Two preterm } \\
\text { births }\end{array}$ & 3 & $3.57 \%$ & $\begin{array}{l}\mathrm{X}^{2}=0.2605 \\
\mathrm{p}=0.6098\end{array}$ \\
\hline $\begin{array}{l}\text { One abortion } \\
\text { \& one preterm } \\
\text { birth }\end{array}$ & 6 & $7.14 \%$ & $\begin{array}{l}\mathrm{X}^{2}=1.4119 \\
\mathrm{p}=0.2347\end{array}$ \\
\hline $\begin{array}{l}\text { One ectopic } \\
\text { One }\end{array}$ & 2 & $2.38 \%$ & $\begin{array}{l}\mathrm{X}^{2}=0.0242 \\
\mathrm{p}=0.8763\end{array}$ \\
\hline
\end{tabular}

Among the 22 multiparous who were pregnant for more than 4 times, $9.1 \%$ each had a previous history of 1 abortion, 2 abortions and 1 preterm birth.

$13.64 \%$ had a previous history of 3 abortions prior to this pregnancy.

1 patient each had a history of 2 and 3 preterm births prior to this pregnancy (Table $4 \mathrm{c}$ ). 
Table 4c: Gravida 4 and above: $(n=22)$.

\begin{tabular}{|llll|}
\hline Past history & $\begin{array}{l}\text { No. of } \\
\text { cases }\end{array}$ & $\begin{array}{l}\text { Percentage } \\
(\mathrm{n}=22)\end{array}$ & $\begin{array}{l}\mathrm{X}^{2} \\
\mathrm{p} \text { value }\end{array}$ \\
\hline One abortion & 2 & $9.1 \%$ & $\begin{array}{l}\mathrm{X}^{2}=0.0601 \\
\mathrm{p}=0.8063\end{array}$ \\
\hline Two abortions & 2 & $9.1 \%$ & $\begin{array}{l}\mathrm{X}^{2}=0.0601 \\
\mathrm{p}=0.8063\end{array}$ \\
\hline $\begin{array}{l}\text { Three abortions } \\
\begin{array}{l}\text { One preterm } \\
\text { birth }\end{array}\end{array}$ & 2 & $13.64 \%$ & $\begin{array}{l}\mathrm{X}^{2}=0.0077 \\
\mathrm{p}=0.9302\end{array}$ \\
$\begin{array}{l}\text { Two preterm } \\
\text { births }\end{array}$ & 1 & $4.1 \%$ & $\begin{array}{l}\mathrm{X}^{2}=0.0601 \\
\mathrm{p}=0.8063\end{array}$ \\
\hline $\begin{array}{l}\text { Three preterm } \\
\text { births }\end{array}$ & 1 & $4.55 \%$ & $\begin{array}{l}\mathrm{X}^{2}=0.6821 \\
\mathrm{p}=0.4089\end{array}$ \\
\hline
\end{tabular}

Among the 410 cases of preterm labour, it was observed that, $327(79.76 \%)$ patients had one or multiple risk factors while $83(20.24 \%)$ patients did not have any identifiable risk factor:

1. Diabetes in pregnancy was noted in 14 patients with preterm labour accounting for $3.41 \%$. This association was found to be statistically significant.

2. Hypertensive disorders were commonly associated with preterm births, accounting for $21.07 \%$. It was the most common indication for iatrogenic preterm delivery. This association was found to be statistically significant.

3. 64 patients with singleton pregnancies had malpresentation and 12 patients with multiple gestation presented with malpresentation of the presenting twin. Malpresentation accounting totally for $18.54 \%$ of cases. This association was found to be statistically significant.

4. 40 cases $(9.76 \%)$ presented with multiple pregnancy which included 2 triplet pregnancies. Out of the 40 cases of multiple pregnancy, 1 triplet presented with intrauterine demise of 2 triplets. This association was found to be statistically significant.

5. 45 patients presented with antepartum haemorrhage, 19 with placenta previa and 26 with abruptio placenta. This association was found to be statistically significant.

6. $13.65 \%$ patients presented with urinary tract infection. This association was found to be statistically significant.

7. 3 patients had uterine anomalies; 1 with bicornuate uterus and 2 with septate uterus.

8. 6 patients presented with polyhydramnios
9. $2.68 \%$ had anaemia, $1.46 \%$ had upper respiratory tract infection. $0.49 \%$ each had bronchial asthma, heart disease and hypothyroidism. 6 patients presented with pyrexia, out of which 2 had malaria.

Table 5: Distribution of cases according to presence of risk factors in the index pregnancy.

(Total No. of patients with risk factors: 327; Total No. of patients without risk factors: 83)

\begin{tabular}{|lllll|}
\hline Risk factors & $\begin{array}{l}\text { No. of } \\
\text { cases }\end{array}$ & $\begin{array}{l}\text { Percentage } \\
(\mathrm{n}=410)\end{array}$ & $\mathbf{X}^{2}$ & $\begin{array}{l}\mathrm{p} \\
\text { value }\end{array}$ \\
\hline GDM & 14 & $3.41 \%$ & 7.1545 & 0.0075 \\
\hline Anemia & 11 & $2.68 \%$ & 5.2822 & 0.0215 \\
\hline $\begin{array}{l}\text { Hypertensive } \\
\text { disorders }\end{array}$ & 89 & $21.07 \%$ & 60.88 & 0.0000 \\
\hline UTI & 56 & $13.65 \%$ & 35.574 & 0.0000 \\
\hline URTI & 6 & $1.46 \%$ & 2.2463 & 0.1339 \\
\hline $\begin{array}{l}\text { Bronchial } \\
\text { asthma }\end{array}$ & 2 & $0.49 \%$ & 0.1414 & 0.7069 \\
\hline Hypothyroidism & 2 & $0.49 \%$ & 0.1414 & 0.7069 \\
\hline Heart disease & 2 & $0.49 \%$ & 0.1414 & 0.7069 \\
\hline Fever/malaria & 6 & $1.46 \%$ & 2.2463 & 0.1339 \\
\hline $\begin{array}{l}\text { Multiple } \\
\text { gestation }\end{array}$ & 40 & $9.77 \%$ & 24.278 & 0.0000 \\
\hline Hydramnios & 6 & $1.46 \%$ & 0.2463 & 0.1339 \\
\hline APH & 45 & $10.97 \%$ & 27.745 & 0.0000 \\
\hline $\begin{array}{l}\text { Uterine } \\
\text { anomalies }\end{array}$ & 3 & $0.07 \%$ & 0.5763 & 0.4478 \\
\hline Malpresentation & 76 & $18.54 \%$ & 49.243 & 0.0000 \\
\hline
\end{tabular}

*The total No. of cases however, does not sum up to 327 as there were cases with multiple risk factors in the same patient.

Table 6: Evaluation of bacteriological profile in vaginal and urine samples.

(Total No. of patients with UTI: 56; Total No. of patients without UTI: 354; Total No. of patients with vaginal infection: 34; Total No. of patients without vaginal infection: 376 )

\begin{tabular}{|lllll|} 
Organisms & $\begin{array}{l}\text { No. of } \\
\text { urine } \\
\text { samples }\end{array}$ & $\begin{array}{l}\text { Percent } \\
(\mathbf{n = 4 1 0})\end{array}$ & $\begin{array}{l}\text { No. of } \\
\text { vaginal } \\
\text { swab } \\
\text { samples }\end{array}$ & $\begin{array}{l}\text { Percent } \\
(\mathbf{n}=410)\end{array}$ \\
\hline E.coli & 34 & $8.29 \%$ & - & - \\
\hline Acinetobacter & 11 & $2.68 \%$ & - & - \\
\hline Klebsiella & 4 & $0.97 \%$ & 2 & $0.48 \%$ \\
\hline Candida & - & - & 26 & $6.34 \%$ \\
\hline S.aureus & - & - & 4 & $0.97 \%$ \\
\hline Others & 7 & $1.07 \%$ & 2 & $0.48 \%$ \\
\hline Contaminated & 109 & $26.58 \%$ & 17 & $4.14 \%$ \\
\hline Sterile & 245 & $59.76 \%$ & 350 & $85.36 \%$ \\
\hline Total & 410 & $100 \%$ & 410 & $100 \%$ \\
\hline
\end{tabular}

Chi-square test for UTI: $\mathrm{X}^{2}=35.574 ; \mathrm{p}=0.0000$

Chi square test for vaginal infections: $X^{2}=20.193 ; p=0.0000$ 
UTI was present in 56 patients (13.65\%). The commonest causative organism of urinary tract infection was $E$. coli $(8.29 \%)$. Some of the other causative organisms of urinary tract infection were Klebsiella, Acinetobacter, Enterobacter and Pseudomonas. The association between preterm labour and UTI was found to be statistically significant. Vaginal infections were present in 34 patients $(8.29 \%)$. The commonest organism being Candida albicans $(6.34 \%)$. The other organisms were S. aureus, Klebsiella and other species of Candida. This association was also found to be statistically significant.

\section{DISCUSSION}

In our study, out of the 5246 patients who delivered beyond 28 weeks, 606 cases presented in threatened preterm labour/preterm labour.

Out of the 606 patients, 196 were in threatened preterm labour. These patients were excluded from further analysis. The remaining 410 patients delivered preterm. Therefore, the true incidence of preterm births in our study was $7.81 \%$. This was in close agreement to the worldwide incidence of preterm births; Stacy Beck et al. ${ }^{2}$ who reported an incidence of $6-11 \%$ and Cooper et al. ${ }^{3}$ at $7-11 \%$. However, Singh Uma et al. ${ }^{6}$ in their study reported an incidence of preterm births as $20.9 \%$ and incidence of preterm labour as $22 \%$.

This difference may be due to differences in socioeconomic status of subjects, poverty, nutrition, literacy and awareness of antenatal care between the two states where these studies were undertaken.

\section{Age incidence}

Maximum number of cases of preterm labour in our study was in the age group 25-29 years, accounting for 35.7\% of cases. This was followed by $32.2 \%$ in the age group 20-24 years. Thus, it may be noted that $67.9 \%$ cases were in the age group of 20-29 years. Extremes of age group accounted for $15.8 \%$ of cases (Table 1).

The present study is comparable to study done by Renay Weiner et al in Kenya ${ }^{7}$ wherein $18.8 \%$ of cases were in the extremes of reproductive age group.

In a study done by Samim A et al. in Iraq $2006,{ }^{8}$ extremes of reproductive age group accounted for $36.5 \%$ of cases and $45 \%$ of cases in age group 20-29 years. This is in contrast and more than twice the number in our study. This could be because of the low absolute number at extremes of age in this study, with only 27 patients $<19$ years of age and 38 patients $>35$ years of age.

\section{Gravidity and preterm labour}

$45.61 \%$ who presented in preterm labour were primigravidas in our study, while multigravidas accounted for $54.39 \%$ (Table 2).
The findings in the present study are consistent with the study by Singh Uma et al. $^{6}$ where $47 \%$ were primigravidas and $53 \%$ were multiparous. Also, in a study by SJ Etuk et al., ${ }^{9} 41.94 \%$ were primigravida and $58.06 \%$ were multigravidas.

\section{Parity and preterm labour}

In our study $50.02 \%$ of multigravidas were pregnant for the second time, $37.67 \%$ for the third time, $8.97 \%$ for the fourth time and $1.3 \%$ were grand multiparas (Table 3 ).

This is comparable to a study by Samim $\mathrm{S}$ et al. ${ }^{8}$ in which second gravidas accounted for $56 \%, 11.5 \%$ were pregnant for the third time and $11 \%$ for the fourth time. In their study, however, $21.5 \%$ were grand multiparas.

In a longitudinal case series examining demographic and obstetric data of 17493 deliveries conducted in a referral centre in Israel preterm delivery rate was much higher in grand multiparas(93\% among gravid $>5){ }^{10}$

The higher incidence of preterm births in grand multiparas in their studies may be explained by the social norms of big families that exist in Muslim countries. In our institution, patients are highly motivated to adopt methods of family planning and so the percentage of grand multiparas was much lower in this study.

\section{Past obstetric history}

In our study, $30.49 \%$ of patients who presented in preterm labour had a history of one abortion (Table 4). This was in contrast to the incidence reported by Arias et al i.e. $13 \%{ }^{11}$

Table 7: Comparison.

\begin{tabular}{|lll|}
\hline & Present study & Arias et al. ${ }^{11}$ \\
\hline H/O one abortion & $30.49 \%$ & $13 \%$ \\
\hline H/O three abortion & $3.14 \%$ & $9.39 \%$ \\
\hline
\end{tabular}

There was also a discrepancy in the incidence of preterm births among those patients with history of two and three abortions. The reason could be due to a small number of patients in either group which makes a comparison difficult.

In a case control study done in Iraq, ${ }^{8} 15 \%$ patients had a history of previous preterm birth. In comparison, $12.11 \%$ patients in our study had history of preterm births.

According to a study by Pandey Kiran et al., ${ }^{12} 14.4 \%$ of patients had a previous history of preterm births and $14.4 \%$ had a previous history of abortion. In our study also, $12.11 \%$ had a history of previous preterm births. However, $35 \%$ of patients in our study who presented in preterm labour had a previous history of abortions. 


\section{Antenatal risk factors and preterm labour}

Among the 410 cases of preterm labour, it was observed that, $347(79.76 \%)$ patients had one or more risk factors while $83(20.24 \%)$ patients did not have any identifiable risk factor (Table 5).

1. Hypertensive disorders were noted in $21.07 \%$ in our study. This was comparable to studies by SJ Etuk et al.9 at $23.8 \%$, Shreshta S et al.13 at $13.3 \%$, Taskeen Rehana14 at $14 \%$. The higher incidence of hypertensive disorders in our study could be due to the fact that most cases in the present study cohort were referred/unbooked with no proper antenatal care and the institution was a tertiary care centre which caters to most of high risk pregnancies.

2. UTI was present in $13.65 \%$ of patients in our study as against $20.34 \%$ the study by Pandey et al. ${ }^{12}$ and $40 \%$ in a case control study in Iraq $2006 .{ }^{8}$ The difference could be due to differences in the criteria used to diagnose UTI, whether based on clinical symptoms or by urine culture.

3. Gestational diabetes was present in $3.41 \%$.This was comparable to a study by Taskeen Rehana ${ }^{14}$ who reported an incidence of $4 \%$.

4. Hydramnios was noted in $1.46 \%$. In a study on outcome of preterm babies and associated risk factors in a hospital in Nepal, ${ }^{13} 0.7 \%$ presented with hydramnios. In their study Pandey Kiran ${ }^{12}$ et al. reported an incidence of, $0.79 \%$ of hydramnios.

5. Uterine anomalies were noted in $0.07 \%$ of patients in our study as against $4.82 \%$ in the study by Pandey Kiran et al. ${ }^{12}$ Majority of the patients were unbooked without prior evaluation. It is possible that some of the uterine anomalies were undiagnosed.

6. Malpresentation of the presenting part was found in $18.54 \%$ of patients presenting in preterm labour (Table 5). $30 \%$ of patients who presented with multiple pregnancy had the presenting twin in a presentation other than vertex. Our incidence is in agreement with the incidence reported by Taskeen Rehana $^{14}$ in her study (21\%), indicating that malpresentation is an important risk factor for preterm labour.

\section{Bacteriological profile}

The incidence of UTI in our study was $13.65 \%$ as against $20.34 \%$ in a study by Pandey Kiran et al. ${ }^{12}$ and $40 \%$ as reported by Samim $\mathrm{S}$ et al. ${ }^{8}$ The difference could be due to differences in the criteria used to diagnose UTI, whether based on clinical symptoms or by urine culture.
E. coli was most commonly seen causing UTI, in $8.29 \%$ of cases in our study followed by Acinetobacter and Klebsiella (Table 5 and 6).

In our study, vaginal infections were present in $8.29 \%$ (Table 6). The commonest organism was Candida albicans $(6.34 \%)$. The other organisms were S. aureus, Klebsiella and other species of Candida. The incidence of genital tract infections was lower when compared to Samim S et al., ${ }^{8}$ who reported an incidence of $24 \%$.

Funding: No funding sources

Conflict of interest: None declared

Ethical approval: Not required

\section{REFERENCES}

1. Philip Steer. The epidemiology of preterm labour. BJOG. 2005;112(Suppl 1):1-3.

2. Stacy B, Daniel W, Lale S, Ana Pilar B, Mario M, Jennifer HR, et al. The worldwide incidence of preterm birth: a systematic review of maternal mortality and morbidity. Bull World Health Organ. 2010;88:31-8.

3. Copper RL, Goldenberg RL, Creasy RK, DuBard MB, Davis RO, Entman SS, et al. A multicenter study of preterm birth weight and gestational age specific neonatal mortality. Am J Obstet Gynecol. 1993;168:78-84.

4. Villar J, Abalos E, Carroli G, Giordano D, Wojdyla D, Piaggio G, et al. Heterogeneity of perinatal outcomes in the preterm delivery syndrome. Obstet Gynecol. 2004;104:78-87.

5. Lumley J. Defining the problem: the epidemiology of preterm birth. BJOG. 2003;110(Suppl 20):3-7.

6. Singh Uma, Singh Nisha, Seth Shikha. A prospective analysis of etiology and outcome of preterm labour. J Obstet Gynecol India. 2007;57(1):48-52.

7. Renay Weiner, Carine Ronsmans, Ed Dorman, Hilton Jilo, Anne Muhoro, Caroline Shulman. Labour complications remain the most important risk factors for perinatal mortality in rural Kenya. Bull World Health Organ. 2003;81:561-6.

8. Samim A Al-Dabbagh, Wafa Y Al-Taee. Risk factors for preterm birth in Iraq: A case-control study. BMC Pregnancy Childbirth. 2006;6:13.

9. Etuk SJ, Etuk IS, Oyo-ita AE. Factors influencing the incidence of preterm birth in Calabar, Nigeria. Niger J Physiol Sci. 2005;20(1-2):63-8.

10. Shlomo E, Ehud W, Zohar N, Eliezer S. Epidemiologic risk factors for preterm delivery. Isr Med Assoc J. 2002;4:1115-7.

11. Arias F. PTL. In: Arias F, eds. Practical Guide to High Risk Pregnancy and Delivery. 2nd ed. St Louis: Mosby Year Book; 1993: 80-81.

12. Pandey K, Bhagoliwal A, Gupta N, Katiyar G. Predictive value of various risk factors for preterm labour. J Obstet Gynaecol India. 2010;60(2):141-5.

13. Shreshta S, Dangol Singh S, Shreshta M, Shreshta RPB. Outcome of preterm babies and associated risk 
factors in a hospital. J Nepal Med Assoc. 2010;50(180):286-90.

14. Taskeen Rehana. Preterm delivery. A major predictor of perinatal morbidity and mortality. JPMI. 2006;20(3):279-83.
Cite this article as: Fernandes SF, Chandra S. A study of risk factors for preterm labour. Int J Reprod Contracept Obstet Gynecol 2015;4:1306-12. 